\author{
Elena Koverzanova ${ }^{1}$, Sergei Usachev ${ }^{1}$, Klara Gumargalieva ${ }^{1}$ and Leonid Kokov ${ }^{2}$
}

\title{
POSSIBILITY OF USING EMBOLIZING PREPARATION DERIVED FROM POLY(2-HYDROXYETHYL METHACRYLATE) (POLY-HEMA) FOR CHEMOEMOBOLIZATION
}

\author{
${ }^{1}$ N.N. Semenov Institute of Chemical Physics, RAS, 4 Kosygin st., M oscow 11999, Russia, \\ stusl@chph.ras.ru \\ ${ }^{2}$ A.V. Vishnevsky Institute of Surgery, 27 Bol. Serpukhovskaya st., \\ M oscow 115093, Russia.
}

Received: October 23, 2008

(c) Koverzanova E., Usachev S., Gumargalieva K., Kokov L. 2009

\begin{abstract}
The principal opportunity of uptaking weakly crosslinked hydrogel emboli is shown by Doxorubicin at different temperatures. The optimal process time is 1.5$2.5 \mathrm{~h}$. It is revealed that Doxorubicin is capable to diffuse from a polymeric matrix, having targeted medical effect on surrounding tissue and reducing side impacts on other organs.
\end{abstract}

Keywords: 2-hydroxyethyl methacrylate, emboli, Doxorubicin, drug uptake, drug release.

\section{Introduction}

Weakly crosslinked hydrogels derived from hydroxyethyl methacrylate (HEMA) are representatives of a broad class of biomedical polymers. Their basic advantages are: high porosity, swelling properties in aqueous solution $(65 \%)$, elasticity and resistance to biological environment. These are the properties which assign high biocompatibility of the material to the organism tissues that allow the performance of purposeful occlusive embolization of vessels in order to arrest bleeding or to reduce blood filling in pathologies of various origins.

Now there is no doubt in urgency of the embolization method, which allows the selective impact on the damaged organ. However, in some cases (malignant neoplasms) this procedure requires additional application of medicinal preparations. As these preparations are injected in a traditional manner, they affect all organs in the organism, including the damaged ones. It explains searching for a solution, which would allow the targeted effect of cytostatics on the damaged organ and, therefore, reduction of adverse side effects. The studies performed in this direction indicate that in some cases, at simultaneous use of cytostatic preparations and embolization of vessels, the greater effect than in the case of individual use of embolization method can be reached [1-4]. Although embolizing systems used in these works had different chemical and physical properties, all authors indicate a significant increase of curative antitumor effect without increasing the total dose of the drug and reduction of total toxic load on the patient.

The purpose of this work is the study in vitro of a possibility of cytostatic drug, doxorubicin hydrochloride uptake and release by embologenic material (EM) derived from poly-HEMA determing the concentration dependences of these processes.

\section{Experimental}

In this work weakly crosslinked hydrogel emboli, cylindrically shaped $(\mathrm{D}=1.000 \mu \mathrm{m}, \mathrm{L}=1 \mathrm{~cm})$, synthesized on the basis of 2-hydroxyethyl methacrylate (Fig. 2a) are used. Ethylene glycol dimethacrylate (EGDMA) was used as a crosslinking agent it. In the uptake study two types of emboli - swollen emboli (SE) and preliminarily dried emboli (DE) - were used. Emboli were dried at room temperature up to the establishment of a constant mass; the water loss was $63.89 \pm 0.89 \%$.

The surface and porosity of cylindrical emboli were studied using scanning electron microscope by Jeol YSM5300 LV Company (Japan). The samples were stained by gold sputtering on Jeol YFC-1100 E unit, called "Ion sputtering device". The sputtering thickness is $\sim 40 \mathrm{~A}$.

Uptaking of EM by doxorubicin hydrochloride (Doxorubicin-LENS by LENS-Farm) and releasing of it were controlled by changes in DR concentration in aqueous solutions on spectrophotometer Shimadzu UV160A.

For studying the process of uptaking with emboli 20 pieces of both SE and DE were placed in DR aqueous solution $(7 \mathrm{ml})$ with $0.1 \mathrm{mg} / \mathrm{ml}$ concentration $(0.7 \mathrm{mg}$ DR). Changes of DR concentration were controlled specrophotometrically every $30 \mathrm{~min}$. For studying the process of DR releasing both SE and DE were withdrawn 
from the solution, dried slightly by a blotting paper and placed in $5 \mathrm{ml}$ of distilled water. Changes in DR concentration at release were measured analogously to the uptake process control.

DR uptake and release degrees were estimated by concentration changes in the solution and calculated by the formula:

$$
R=\frac{C_{0}-C_{t}}{C_{0}} \cdot 100
$$

where $C_{0}$ is the initial DR concentration; $C_{t}$ is the current DR concentration.

\section{Results and Discussion}

\subsection{EM Synthesis and Structure}

Synthesis cylindrical emboli on the basis of weakly crosslinked hydrogel was carried out in a water solution under the action of an oxidation-reduction catalyst - ammonium persulphate (APS) - N, N, N', N'-tetramethylethylenediamine (TMED) at $293 \mathrm{~K}$ [5], unlike used before synthesis of poly-HEMA at 353-363 K [6]. Polymerization was carried out in tubes of $12-15 \mathrm{~cm}$ length and $1 \mathrm{~mm}$ in diameter. After polymerization completion hydrogel samples were cut into parts by $1 \mathrm{~cm}$ long and washed at $353 \mathrm{~K}$ changing water regularly during several hours.

Linear macromolecules formed during polymerization of 2-hydroxyethyl methacrylate monomer possess hydrophilic properties. This is the property that allows them to be unlimitedly miscible with water, hence, forming viscous transparent gel (or hydrogel) "solutions". At the polymerization stage, injection of some few (1 \pm $0.5 \%$ ) ethyleneglycol dimethacrylate comonomers capable of embedding between two linear macromolecules forms the so-called cross-linked hydrogels (Fig. 1), which are already insoluble in water. Inherently, all these systems are amorphous and are unable to form any regular structures.

Table 1

The composition of polymerization mixture

\begin{tabular}{|c|c|c|c|c|}
\hline Reagents & $\mathrm{H}_{2} \mathrm{O}$ & $\begin{array}{c}\mathrm{HEM} \\
\text { A }\end{array}$ & $\begin{array}{c}\text { EGD } \\
\text { MA }\end{array}$ & $\begin{array}{c}\text { APS/TM } \\
\text { ED }\end{array}$ \\
\hline Reagent ratio, \% & 67.21 & 31.43 & 1.12 & 0.23 \\
\hline
\end{tabular}

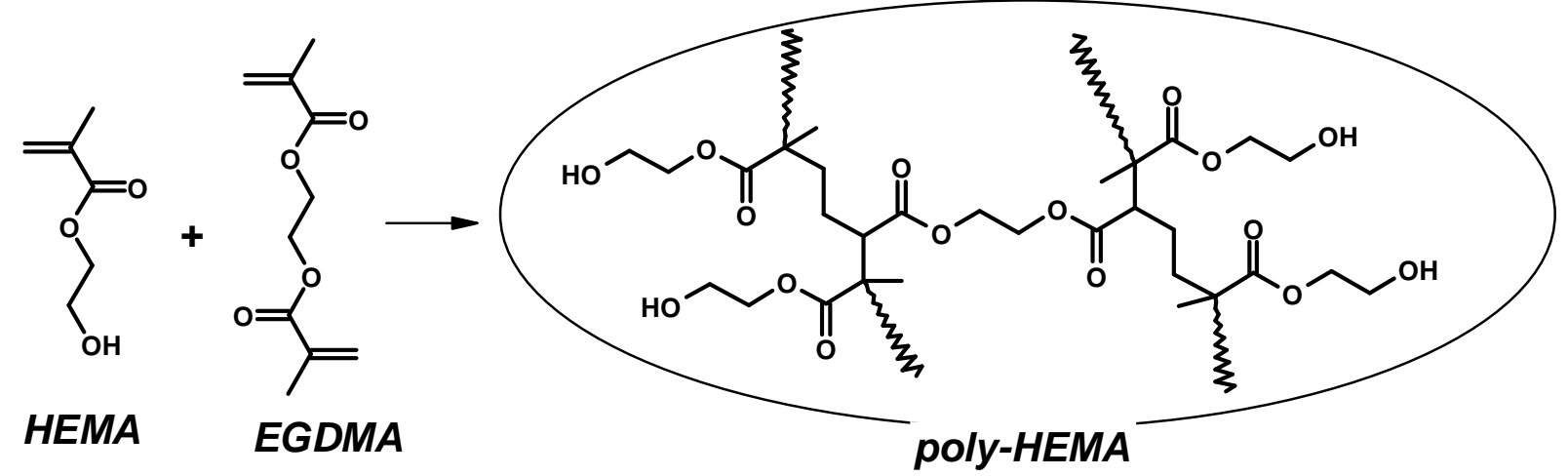

Fig. 1. The formation scheme of cross-linked poly-HEMA hydrogel



a

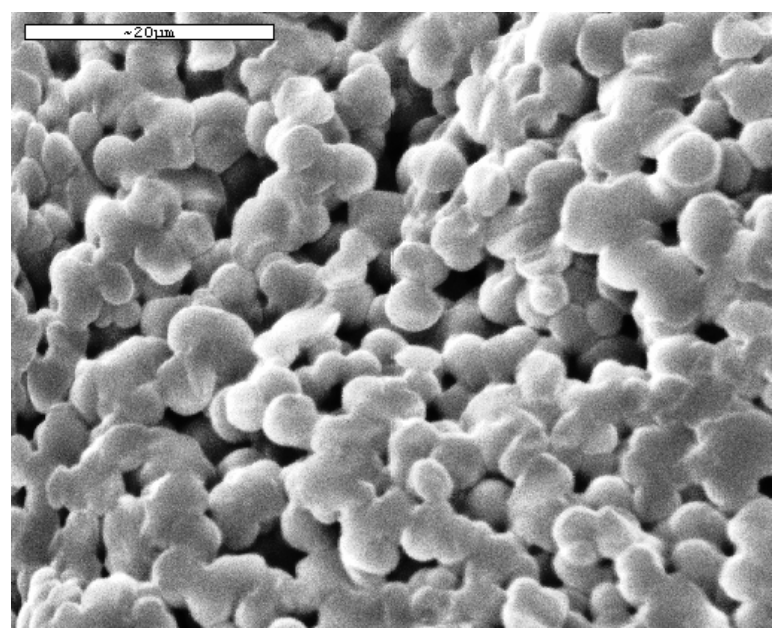

b

Fig. 2. Picture of embologenic material from poly-HEMA, cylinder shaped $(\mathrm{D}=1000 \mu \mathrm{m}, \mathrm{L}=1 \mathrm{~cm})(\mathrm{a})$ and microphotograph of cross-section of the same material (amplified $\times 2000)(b)$ 
However, it has been found that at polymerization carried out under above mentioned conditions a polymeric structure having heterogeneous architecture different from hydrogel is formed (Fig. 2).

Fig. $2 \mathrm{~b}$ shows a conglomerate polymeric structure consisting of globules sized 3-5 $\mu \mathrm{m}$, and the gap among them filled with water. The water content is up to $65 \%$. Hence, high porosity of hydrogels derived from polyHEMA has a positive effect on the material miscibility to organism tissues and promotes the growth of connective fibrous tissue in hydrogel pores during water substitution by blood. This leads to a stable fixation in the blood vessel. Another definite advantage of the porous structure is the possibility to use hydrogel emboli as drug carriers with a controlled drug release.

\subsection{Q uantitative Determination of DR in Aqueous Solutions}

UV-spectrum of DR is characterized by several maxima: three in the UV region (231, 252 and $290 \mathrm{~nm})$ and one in the visible region $(480 \mathrm{~nm})$. For determination of quantitative variations in DR concentration at uptake and release, we have chosen the wavelength of $480 \mathrm{~nm}$. Linear dependence of optical density on the solution concentration is observed in a wide concentration range of 0.2 to $0.005 \mathrm{mg} / \mathrm{ml}$ with the regression coefficient $\mathrm{R}=$ 0.99968 .

\subsection{Uptake of EM by Doxorubicin}

Selection of the time period for emboli uptake (1.5, 2 and $2.5 \mathrm{~h}$ at 293 or $313 \mathrm{~K}$ ) was determined by the possibility of carrying out this procedure directly before embolization. Analysis of kinetic uptake curves (Fig. 3) has shown that for SE the uptake process starts almost immediately. At the initial stages, the uptake rate at $313 \mathrm{~K}$ is higher that at $293 \mathrm{~K}$ (Table 1). Hence, DE uptake proceeds with some delay. It is noted, that in the initial 30 min there is an increase of cytostatic concentration in the solution. This event may be explained by the fact that, primarily, DE is swollen and then DR uptake begins. Gradual penetration of water inside DE causes opening of pores "collapsed" at drying and promotes penetration of DR molecules inside the polymer matrix.

Table 2 shows that at different temperatures SE uptake degrees differ insignificantly. However, they are somewhat higher at $293 \mathrm{~K}$ rather than at $313 \mathrm{~K}$. Thus, as it is shown, DR uptake of cylindrical emboli may be performed at room temperature.

Uptake degrees and rates of DR at different temperatures

\begin{tabular}{|c|c|c|c|c|c|c|}
\hline \multirow{3}{*}{ Uptake time, $\mathrm{h}$} & \multicolumn{3}{|c|}{ Uptake degree, $\%$} & \multicolumn{3}{|c|}{ Uptake rate, $\mathrm{mg} / \mathrm{h}$} \\
\hline & \multicolumn{2}{|c|}{ at $293 \mathrm{~K}$} & \multirow[t]{2}{*}{ at $313 \mathrm{~K}$} & \multicolumn{2}{|c|}{ at $293 \mathrm{~K}$} & \multirow[t]{2}{*}{ at $313 \mathrm{~K}$} \\
\hline & DE & & & $\mathrm{DE}$ & & \\
\hline 0.5 & 0 & 2.16 & 2.99 & 0 & 0.031 & 0.051 \\
\hline 1 & 1.72 & 6.16 & 5.90 & 0.014 & 0.046 & 0.052 \\
\hline 1.5 & 4.23 & 8.82 & 7.13 & 0.022 & 0.044 & 0.042 \\
\hline 2 & 5.55 & 10.39 & 8.43 & 0.022 & 0.039 & 0.037 \\
\hline 2.5 & 5.99 & 11.75 & 8.47 & 0.019 & 0.035 & 0.030 \\
\hline
\end{tabular}

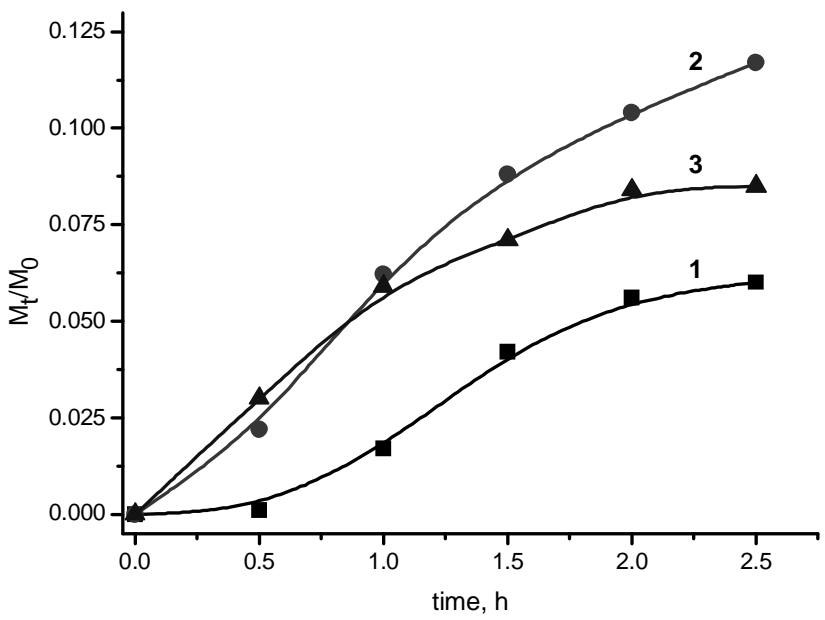

Fig. 3. DR uptake curves of emboli. DE, uptake at $293 \mathrm{~K}$ (1); SE, uptake at $293 \mathrm{~K} \mathrm{(2);} \mathrm{SE,} \mathrm{uptake} \mathrm{at} 313 \mathrm{~K}$

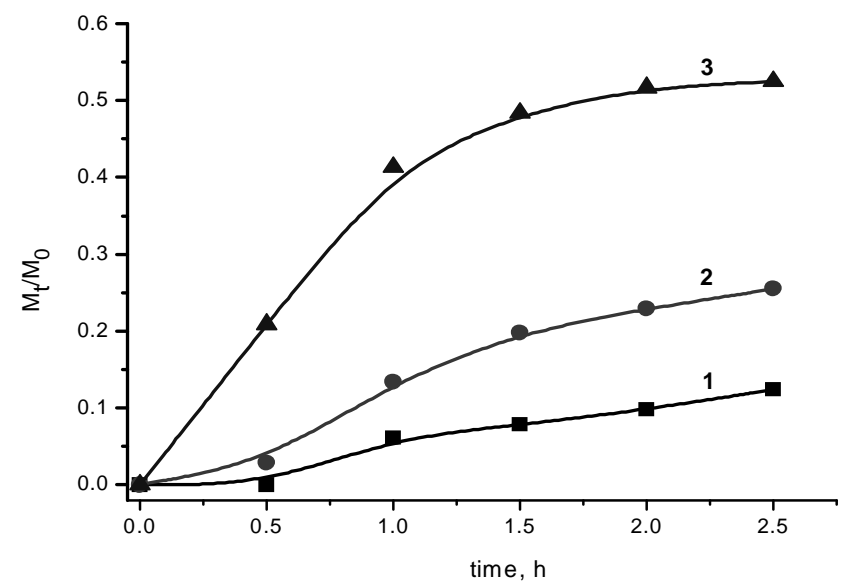

Fig. 4. DR release curves from emboli. DE, uptake at $293 \mathrm{~K}$ (1); SE, uptake at $293 \mathrm{~K}$ (2); SE, uptake at $313 \mathrm{~K}$ (3) 
DR release degrees and rates from cylindrical emboli at different temperatures

\begin{tabular}{|c|c|c|c|c|c|c|}
\hline \multirow{3}{*}{ Uptake time, $\mathrm{h}$} & \multicolumn{3}{|c|}{ Release degree, $\%$} & \multicolumn{3}{|c|}{ Release rate, $\mathrm{mg} / \mathrm{h}$} \\
\hline & \multicolumn{2}{|c|}{ at $293 \mathrm{~K}$} & \multirow[t]{2}{*}{ at $313 \mathrm{~K}$} & \multicolumn{2}{|c|}{ at $293 \mathrm{~K}$} & \multirow[t]{2}{*}{ at $313 \mathrm{~K}$} \\
\hline & $\mathrm{DE}$ & & & $\mathrm{DE}$ & & \\
\hline 0.5 & 0.00 & 0.94 & 20.94 & 0.000 & 0.010 & 0.028 \\
\hline 1 & 6.08 & 13.37 & 41.31 & 0.002 & 0.014 & 0.029 \\
\hline 1.5 & 7.77 & 19.82 & 48.39 & 0.002 & 0.012 & 0.023 \\
\hline 2 & 9.76 & 22.89 & 51.66 & 0.002 & 0.011 & 0.019 \\
\hline 2.5 & 12.39 & 25.45 & 52.47 & 0.002 & 0.010 & 0.015 \\
\hline
\end{tabular}

\subsection{Doxorubicin Release from EM}

The analysis of kinetic curves of DR release from emboli has determined the following regularities. For SE, at temperature of $313 \mathrm{~K}$ (Fig. 4, curve 3) an abrupt DR release is observed: up to $50 \%$ of the preparation is extracted during $2 \mathrm{~h}$. The equilibrium state is reached 2$2.5 \mathrm{~h}$ after the initiation process. DR release from SE at $293 \mathrm{~K}$ (Fig. 4, curve 2) proceeds less intensively than that at $313 \mathrm{~K}$, without a typical effect of explosion. Similar to uptake, half an hour delay of DR release from DE is observed. This may be explained by the fact that for reaching equilibrium swelling, 2.5 hours are not enough for uptake in aqueous solution, and swelling dominates over release.

\section{Conclusions}

Kinetic data on DR uptake of emboli allow to conclude that optimal duration of the process is $1.5-2.5$ hours. Hence, drug uptake from the solution is $11.5 \pm$ $0.25 \%$ (regarding initial DR concentration in the solution). Similar uptake degree may also be expected for higher DR concentrations.

Experimental data on DR uptake of EM and DR release rate to the solution in vitro may be the model for estimation of medicinal preparations behavior in the organism after carrying out chemoembolization. At temperatures approaching in vivo conditions intensive drug release is observed in the initial 2-2.5 hours. However, it should be taken into account that behavior of drugs in the organism (the rate of release from emboli, diffusion to the embolized organ) may differ from the results presented.

Thus, application of embologenic preparations derived from poly-HEMA may be rather prospective in the course of chemoembolization. High porosity of the preparation gives the possibility to make it uptake with water-soluble medicinal forms. It is shown that DR is able to diffuse from the polymeric matrix and, as it may be expected, it will have the extended therapeutic effect on the surrounding tissue and minimize side impacts on other organs.

\section{References}

[1] Pavlovsky A.: Prakticheskaya Onkologiya, 2004, 5, 108.

[2] Jelinkova M., Strohalm J., Etrych T. et al.: Pharmaceutical Research, 2003, 20, 1557.

[3] Horak D., Gumargalieva K., Zaikov G.: [in:] Zaikov G. (Ed.) Chemical reactions in liquid and solid phase. Nova Science Publ., New York 2003, 11-59.

[4] Horak D., Guseinov E., Vishnevskii V. et al.: J. Biomed. Mater. Res., 2000, 5, 184.

[5] Adamyan A., Kokov L., Titova M. et al.: Russian Federation Patent No. 61120, 2007.

[6] Adamyan A., Gumargalieva K., Dan V. et al.: Patent of USSR No. 1403418, 1988.

\section{ПРО МОЖЛИВІСТЬ ВИКОРИСТАННЯ ЕМБОЛІЙНОГО ПРЕПАРАТУ НА ОСНОВІ ПОЛІ(2-ГІДРОКСИЕТИЛ МЕТАКРИЛАТУ) (ПОЛІ-НЕМА) ДЛЯ ХЕМОЕМБОЛІЗАЦЇ̈}

Анотація. На прикладі Доксорубіцину показана принцииова можливість введення частково зшитого гідрогелю емболів при різних температурах. Встановлено, щяо оптимальний час проиесу 1,5-2,5 год. Показано, що Доксорубіиин здатний дифундувати з полімерної матриці, проявляючи цілеспрямовану медичну дію на оточуючі тканини та знижуючи побічний ефект на інші органи.

Ключові слова: 2-гідроксиетил метакрилат, емболі, Доксорубіцин, введення препарату, виділення препарату. 